\title{
Shedding Light on Participation in Open Government Arenas: Determinants of Platform Activity of Web and App Users
}

\author{
Lisa Schmidthuber \\ Johannes Kepler University Linz \\ lisa.schmidthuber@jku.at
}

\author{
Dennis Hilgers \\ Johannes Kepler University Linz \\ dennis.hilgers@jku.at
}

\author{
Thomas Gegenhuber \\ Johannes Kepler University Linz \\ thomas.gegenhuber@jku.at
}

\begin{abstract}
This article develops and tests a model to explain web-based and mobile devices usage by citizens to interact with their local government. By employing literature from diverse fields of information systems research, the authors derive an integrated model that investigates citizen participation on a city improvement platform. The model proposes three overall influences on platform activity: technological influences (perceived ease of use, perceived usefulness), motivational influences (intrinsic motivation and prosocial motivation), and sociodemographic influences (gender, age, education), and is tested among two groups of users (i.e. web page and mobile app users). Empirical results show that platform activity of both web and mobile users is mainly driven by intrinsic and prosocial motivation. Whereas perceived usefulness is positively associated with platform behavior of web users, TAM variables have not effect on mobile users' activity. While gender and age play a role regarding web activity, age and education influence mobile participation.
\end{abstract}

\section{Introduction}

Public sector organizations increasingly make use of information and communication technologies to communicate with externals, among other things, for the benefit of public service quality and efficacy of service delivery $[19,35,49]$. They encourage citizens to participate in new platform-based forms of collaborative activities and to transfer their knowledge and experience to organization. Examples for such platforms are manifold; consider the example of platforms asking citizens to report nonemergency issues in the urban environment (e.g. reporting potholes) and to make suggestions for improvements [34, 37, 42, 60]. Knowledge about the motivation of individuals who participate in this new service mode can contribute to improve platform effectiveness and increase participation [33, 38]. Despite some promising efforts to understand the patterns of communication between administration and citizens by leveraging modern technology as well as citizens motivations for doing so $[52,58]$ we still lack systematic approaches including multiple factors (e.g., digital divide, citizens attitudes toward technology, differences among channels).

Hence, this paper seeks to shed light on following research questions: (1) What motivates and drives citizens to actively contribute to platform-based and government-led forms of collaborative activities? (2) Does platform behavior differ between citizens utilizing mobile devices and those participating via the web platform? To shed light on these questions, an empirical study with users contributing to a platform for reporting non-emergency issues, which is run by a city government's public service administration, was conducted. More specifically, the data set of this quantitative study comprises of (a) citizens communicating with the administration's platform via web $(\mathrm{N}=458)$ and $(\mathrm{b})$ those using mobile devices for interacting $(\mathrm{N}=466)$.

This paper contributes to literature on open and digital government by exploring the determinants of platform activity among web and app users. First, we identify the determinants of citizens' participation in an open and collaborative government by building a conceptual model of the factors driving users' activity in platform-based and government-led forms of collaborative activities. Second, we investigate the influence of the type of technological device as the reason for differences regarding platform behavior and its antecedents. We test the aforementioned model empirically with two groups of platform users (web users and mobile app users) to get indications of the (1) antecedents of individuals' platform activity and (2) differences in platform behavior among web and mobile users. 


\section{Research model and hypotheses}

For answering the research questions, we develop and test a model to explain citizens' usage of web and mobile devices to interact with local government. We put forth an integrated model that explains citizens' online participation in city improvement through extending the technology acceptance model (TAM) by motivation theory and insights from digital divide literature.

\subsection{Open government and citizen participation}

Advances in information and communication technology have stimulated not only businesses and firms to adopt new and innovative ways to interact with customers (e.g., open innovation), but also the public sector and its organizations have introduced new mechanisms to communicate with their stakeholders (e.g., citizens, businesses, universities). Government organizations use technology to involve citizens in government and to collaborate with them in various ways: Known as e-government, government delivers information and services electronically and thus provides access to information 24/7 [30, 43]. Various studies have dealt with egovernment in the previous years (see e.g., [40]). Among others, studies show that citizens accept the leveraging of technology to, for instance, exchange information with government and use e-government services intensively $[7,53,59]$. Beyond egovernment and the provision and exchange of information by using basic web technology (e.g, electronic data interchange, electronic filing system, digital signature, see [39]), the advance of technology has promoted citizen-state interaction. More sophisticated interface and interoperable technologies, chatrooms, and social media enable government to integrate the external environment in administrative processes and government decisionmaking in a new and innovative manner. Government organizations have implemented platforms (e.g., challenge.gov; fixmystreet.com), and invite external actors to collaborate with them [20, 34, 42, 37]. By leveraging platforms, externals are encouraged to share their knowledge, experiences, and ideas with government [21]. The premise is that opening-up government and thereby harnessing externals' input positively impacts public service performance and quality. To reach these aims, externals have to participate in this new mode of interaction and cooperation with the government. Factors that might influence externals' intensity of platform use are discussed in the following sections.

\subsection{Technology acceptance model}

According to TAM [10], IT usage is determined by an individual's behavioral approach to technology use, which is further influenced by an individual's attitude towards using a system and its perceived usefulness. Technology acceptance is defined to be a function of perceived ease of use (PEOU) and perceived usefulness (PU) [10, 11]. These relationships have been empirically tested, among others (e.g., communication systems, specialized business systems, see [31]), in the public sector context. Based on the results of prior studies on citizens' acceptance of technology provided by the government (e.g., e-government, e-democracy applications), first, we assume that perceived usefulness as the extent to which individuals perceive personal benefit from leveraging the platform is positively related to platform activity (Hypothesis 1).

The effect of PEOU on technology acceptance is mixed. On the one hand, various studies have shown that the ease individuals expect from leveraging a technology influences their decision to use it $[7,11$, 24]. On the other hand, an insignificant effect of the variable on behavioral intention or technology use $[10,57]$ is reasoned by the samples' level of computer and internet expertise [7]. Despite of mixed prior results, we add the variable to our framework due to the significance of PEOU in a non-workplace and voluntary usage context $[55,56]$. Second, we thus hypothesize that perceived ease of use as the degree of ease expected from using the platform positively relates to platform activity (Hypothesis 2).

\subsection{Intrinsic and prosocial motivation}

In addition to TAM, we apply motivation theory to explain individuals' platform activity. Accordingly, individuals' platform activity depends on their willingness to interact with local government and collaborate for the benefit of city improvement. Based on research on motivation [1, 12], we assume that individuals' motivation for engagement in government-led collaborative processes can be (a) intrinsic and (b) prosocial.

First, intrinsic motivation, as "the doing of an activity for its inherent satisfaction rather than for some separate consequences" [12], refers to having fun and feeling enjoyment when performing an activity in contrast to having extrinsic motivation (see perceived usefulness). Empirical studies on 
motivation to participate in open-source projects [29, $36,48]$ show that users contribute to open source software as they enjoy the creative experience. Also citizens' willingness to participate in collaborative projects [58] is mainly driven by fun in participating. Consequently, we hypothesize that users who feel fun and enjoyment when using the platform participate more actively (Hypothesis 3).

Next to intrinsic motivation, second, we expect an effect of prosocial motivation, as the desire to expend effort to benefit other people [1], on platform activity. Individuals decide to spend time on the platform to report defects or communicate with other users about how to arrange public services more effectively. As public services are accessible to the all citizens, every citizen using public services would benefit from improvements. Accordingly, we assume that citizens who invest time in reporting problems about public services are prosocially motivated when interacting with administration and citizen on government-led platforms. Studies on explaining participation on open-source [5, 18, 29, 46, 48] and voluntary engagement in online communities $[4,26$, 60] found that feeling a personal obligation to contribute and altruistic attitudes are reasons for their active participation. Consequently, we thus assume that people who participate due to prosocial motivation are more active on the platform (Hypothesis 4).

\subsection{Digital divide}

As far as citizen-state interactions are concerned, leveraging technology is only one way of getting into contact with, for example, local government. Next to utilizing a computer or a mobile phone to communicate with public officials, citizen can go to a public office to speak with an employee face-to-face or make a phone call. Due to these alternative ways to exchange with administration and based on literature on digital divide $[2,41,44]$, we expect that the group of citizens utilizing the platform actively is predominately male, of young age, and high educated.

For one, we assume that gender influences participation intensity. Whereas some studies have shown that gender is not related to Internet use [2, 53], others confirm that women are less likely to use the Internet for using eGovernment services [54]. The gender gap in participation is also relevant in terms of Wikipedia. Glott et al. (2010) reveal a female contribution rate of under $15 \%$, which is reasoned by women's avoidance of conflicts and their perception to have not enough knowledge and expertise to write contributions [8]. Although the female participation rate in open innovation contests is low, women are more likely to create a winning solution in broadcast search [23]. Based on previous findings, we propose that male users are more actively using the platform (Hypothesis 5). Second, individuals' age is shown to significantly influence technology use. Although older people increasingly use digital technology [9], studies found that younger age cohorts use Internet more frequently than older people for internet voting [51], using e-government [13, 42], or writing Wikipedia contributions [15]. Third, it is shown that although older people increasingly use mobile phones, they are passive users [27]. Consequently, we hypothesize that young users show higher platform activity than older ones (Hypothesis 6). Finally, e-citizens tends to be high educated [2, 50, 53], so that we assume that high educated users are more active on the platform (Hypothesis 7).

\subsection{Web versus mobile user}

Local governments increasingly seek to establish additional channels of communication. In response to recent trends, citizens have the choice in online interaction with the administration to use the website or an application on their mobile phones. This means that individuals frequently are able to use different channels for participating in open government. Many studies investigating online and offline participation show that online participation is a distinct type of participation [47]. People leveraging technology for participation are empirically shown to differ regarding age [3, 47], gender, and education [25] from those participation via traditional and offline channels. In this research, we focus on computers and mobile phones as channels to communicate and interact with government. Based on prior studies showing that offline citizens and their antecedents for participation differ from online ones, we investigate web and mobile participation and examine differences regarding antecedents of participation intensity due to the channel use. We thus test the model with web and mobile users.

\section{Research design}

\subsection{Setting, data collection, and sample}

Empirical research was conducted by distributing an online survey to individuals registered on a platform for communicating with administration for public services reporting. The platform was implemented by the local government, and is operated by public officials. Citizens are invited to 
inform administration about defects of public services or to make requests. Registration on the platform is for free, and the service can be used by webpage or by installing the application on a mobile phone (Android or Apple iOS).

After a pre-test, we sent a questionnaire to 2,200 registered users to make sure that all respondents have gathered some experience with using the platform or application. In total, we received 773 completed questionnaires, corresponding with a response rate of 35.14 percent. To test for nonresponse bias, we examined differences between respondents and non-respondents. A t-test showed no significant differences between the two groups. $58 \%$ of them or 447 respondents have communicated with local government via the website. $55 \%$ of the sample (425 respondents) have downloaded the application and interacted via mobile phone. 130 individuals (17 $\%$ of the sample) said to use both the computer and the mobile phone to get into contact with administration.

\subsection{Research method}

Quantitative analyses were employed to provide an understanding of the factors influencing platform activity of web and mobile users. First, we applied principal component analysis with varimax rotation to extract factors regarding users' reasons for use the platform via the web browser or mobile application $[14,16]$. We use this measure to cluster variables with high correlations into principal components and consequently reduce the number of explanatory variables by tying information in transformed factors [32]. Second, we run linear regression analyses to explain platform activity for both individuals communicating with administration via web page and those using the mobile phone for interaction.

\subsection{Research methodology and operationalization}

3.3.1. Platform activity. Similar to prior research on platform behavior, see e.g., [22], we distinguish between different types of platform activity. Platform activity is measured by a scale aggregating individuals' frequency of writing contributions, commenting on contributions and reading contributions and comments (each measured from $1=$ never to $5=$ always). Whereas reading reports and comments can be seen as passive platform behavior, the activity level increases when users write comments to their reports. Lastly, writing reports, for example, for informing administration about a broken street-light is defined as active platform behavior. Based on the varying levels of activity when performing the three activities, we multiplied the frequency of commenting by two, frequency of writing reports by three to capture the different degrees of platform activity. Frequency distributions of dependent variables are illustrated in Figure 1a for web users and Figure $1 \mathrm{~b}$ for mobile users.



Notes: $\mathrm{N}=398$, Mean=14.8, S.D.=3.95

Figure 1a. Distribution of platform activity among web users

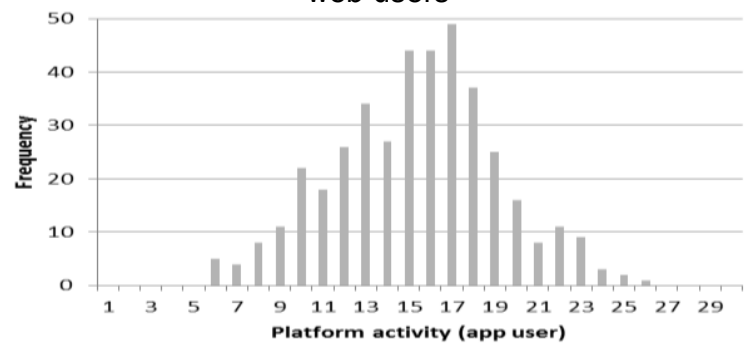

Notes: $\mathrm{N}=404$, Mean=15.33, S.D.=3.85

Figure 1b. Distribution of platform activity among app users

3.3.2. Technology acceptance model and motivation variables. First, TAM variables, perceived usefulness and perceived ease of use, are measured on four-item Likert scales (1=totally disagree; 4=totally agree). Table 1 outlines the items for measuring PU and PEOU. For measuring individuals' motivation to interact with local government for the benefit of public service improvement, respondents were asked to which extent they agree to nine reasons for platform participation. These items (listed in Table 1) were drawn from prior research studying individuals' motivation to use a platform or collaborate with administration, e.g., [11, 28, 26, 48, 46, 58].

For identifying clusters in the variables on the reasons for platform participation and test TAM components, we conduct a principal component analysis for both web and mobile user. The analysis results in four factors for both web and mobile users. 
Table 2 outlines the four constructs for web and mobile users. First, perceived usefulness, explaining 20.86 of the variance for web users and 20.22 for mobile users, is confirmed to be a component distinct from other variables included in the analysis. Second, perceived ease of use, a component with 4 items, explains 17.08 of the variance for web users and 17.52 for mobile users.

Table 1. Constructs and corresponding items

\begin{tabular}{|c|c|c|}
\hline Constructs & Items & \\
\hline \multirow[t]{5}{*}{$\begin{array}{l}\text { Perceived } \\
\text { usefulness }\end{array}$} & PU1 & $\begin{array}{l}\text { The answers provided by the local } \\
\text { government are comprehensible } \\
\text { to me. }\end{array}$ \\
\hline & PU2 & $\begin{array}{l}\text { The answers provided by the local } \\
\text { government are satisfying. }\end{array}$ \\
\hline & PU3 & $\begin{array}{l}\text { My concerns are taken seriously } \\
\text { by the local government. }\end{array}$ \\
\hline & PU4 & $\begin{array}{l}\text { My concerns are processed and } \\
\text { dealt with quickly thanks to the } \\
\text { [platform]. }\end{array}$ \\
\hline & PU5 & $\begin{array}{l}\text { Local government is citizen- } \\
\text { oriented through the [platform] }\end{array}$ \\
\hline \multirow{4}{*}{$\begin{array}{l}\text { Perceived } \\
\text { ease of use }\end{array}$} & PEOU1 & easy to use \\
\hline & PEOU2 & clearly arranged \\
\hline & PEOU3 & visually appealing \\
\hline & PEOU4 & all in all successful \\
\hline \multirow[t]{9}{*}{ Motivation } & M1 & $\begin{array}{l}\text { forwarding concerns easily to } \\
\text { local government }\end{array}$ \\
\hline & M2 & $\begin{array}{l}\text { direct exchange with local } \\
\text { government }\end{array}$ \\
\hline & M3 & participating in public discussion \\
\hline & M4 & $\begin{array}{l}\text { exchanging with like-minded } \\
\text { people experience in using similar } \\
\text { platforms }\end{array}$ \\
\hline & M5 & sharing opinion \\
\hline & M6 & $\begin{array}{l}\text { experience in using similar } \\
\text { platforms }\end{array}$ \\
\hline & M7 & platform use is fun \\
\hline & M8 & $\begin{array}{l}\text { contribution to improvement of } \\
\text { the city }\end{array}$ \\
\hline & M9 & interest in local politics \\
\hline
\end{tabular}

As far as variables on motivation are concerned, for one, people participate on the platform due to reasons such as enjoyment in communicating with like-minded people on the platform, sharing opinions, and discussing with other users. This component indicates intrinsic motivation of respondents to use the platform. Second, items related to prosocial motivation build a factor. Respondents said that they use the platform to communicate in an easy way with government, directly exchange with it, and support city improvement. In both groups of users, variable M9 on interest in local politics has to be excluded from the analysis, as the loading of the variables was below .5.
Table 3 and 4 give further information on the principal components among web and mobile users, and refers to the value of the Cronbach alpha coefficient for all constructs. Whereas it is greater than 0.8 for PU, PEOU, and IM, the component on prosocial motivation (PM) is above 0.6 , an adequate factor reliability for explanatory research according to Nunnally (1978).

Table 2. Principal component analysis of all measurement items (varimax rotation)

\begin{tabular}{|c|c|c|c|c|}
\hline \multirow[b]{2}{*}{ Constructs } & \multicolumn{2}{|c|}{ Web user } & \multicolumn{2}{|c|}{ Mobile user } \\
\hline & Items & Loadings & Items & Loadings \\
\hline \multirow{5}{*}{$\begin{array}{l}\text { Perceived } \\
\text { usefulness }\end{array}$} & PU3 & .867 & PU3 & .873 \\
\hline & PU2 & .843 & PU2 & .843 \\
\hline & PU1 & .836 & PU1 & .822 \\
\hline & PU4 & .776 & PU4 & .778 \\
\hline & PU5 & .699 & PU5 & .600 \\
\hline \multirow{4}{*}{$\begin{array}{l}\text { Perceived } \\
\text { ease of } \\
\text { use }\end{array}$} & PEOU2 & .857 & PEOU2 & .871 \\
\hline & PEOU4 & .835 & PEOU4 & .832 \\
\hline & PEOU3 & .800 & PEOU3 & .789 \\
\hline & PEOU1 & .785 & PEOU1 & .773 \\
\hline \multirow{5}{*}{$\begin{array}{l}\text { Intrinsic } \\
\text { motivation }\end{array}$} & M4 & .858 & M4 & .857 \\
\hline & M5 & .832 & M5 & .815 \\
\hline & M3 & .717 & M3 & .760 \\
\hline & M6 & .697 & M6 & .712 \\
\hline & M7 & .563 & M7 & .549 \\
\hline \multirow{3}{*}{$\begin{array}{l}\text { Prosocial } \\
\text { motivation }\end{array}$} & M1 & .786 & M1 & .797 \\
\hline & $\mathrm{M} 2$ & .731 & $\mathrm{M} 2$ & .696 \\
\hline & M8 & .583 & M8 & .661 \\
\hline
\end{tabular}

Notes: Web users: N=370; KMO: .851, Bartlett-test: $2800.95^{* * *}$, df: 136,5 iterations

Mobile users: $\mathrm{N}=381, \mathrm{KMO}$. 862 , Bartell-test:

3131.84***, df: 136, 5 iterations

Table 3. Web user

\begin{tabular}{l|llll}
\multicolumn{1}{c}{} & PU & PEOU & IM & PM \\
\hline Eigenvalues & 3.55 & 2.9 & 2.84 & 1.77 \\
Variance explained & 20.86 & 17.08 & 16.73 & 10.43 \\
$\mathrm{~N}$ & 410 & 409 & 408 & 419 \\
Mean & 16.24 & 13.81 & 9.4 & 10.76 \\
SD & 3.26 & 2.05 & 3.09 & 1.46 \\
Cronbach's Alpha & .892 & .864 & .809 & .615
\end{tabular}


Table 4. Mobile user

\begin{tabular}{l|llll}
\multicolumn{1}{c|}{} & PU & PEOU & IM & PM \\
\hline Eigenvalues & 3.44 & 2.98 & 2.91 & 1.95 \\
Variance explained & 20.22 & 17.52 & 17.13 & 11.5 \\
$\mathrm{~N}$ & 407 & 414 & 401 & 405 \\
Mean & 16.62 & 13.87 & 9.07 & 10.80 \\
SD & 3.11 & 2.2 & 3.23 & 1.45 \\
Cronbach's Alpha & .888 & .877 & .806 & .631
\end{tabular}

3.3.4. Socio-demographic characteristics. For measuring the effect of socio-demographic characteristics on platform behavior, gender, age, and education of platforms users are included into the analysis. Gender was measuring by a dummy variable (male $=1$, female $=0$ ), age is measured by three categories $(<29=$ young age, $30-49=$ middle age, 50+=old age), and education is distinguished on three levels (low education, middle education, high education).

\subsection{Research model}

Figure 2 shows the research model. Three groups of variables are assumed to explain platform activity. Platform activity is expected to be a function of technological factors (i.e., PU, PEOU), motivational variables (i.e., intrinsic and prosocial motivation), and socio-demographic characteristics (i.e., age, gender, education). We test the hypotheses among web and mobile users to investigate if the technology utilizing for communicating with local government influence the relationship between explanatory variables and platform activity.

\section{Results}

\subsection{Descriptive results}

The characteristics of the sample are outlined in Table 5. Majority of web users ( $47 \%$ ) are aged above 50. About 67 per cent of the web sample is male, and the 76 per cent have a middle or high educational level. Individuals communicating with local government via mobile phone are on average at middle age (between 30 and 49), 74 per cent of application users are male, and about 34 per cent are high educated. As far as platform activity is concerned, descriptive results show that web and mobile users do not differ greatly regarding platform behavior. On a scale from 1 (never) to 5 (always), reading reports and comments is most frequently done at the platform. The value referring to passive platform behavior is higher among mobile user. Next to reading, users report to frequently writing requests on the platform and thus use the platform actively. Lastly, interacting on the platform by commenting reports is the least frequent type of platform behavior.

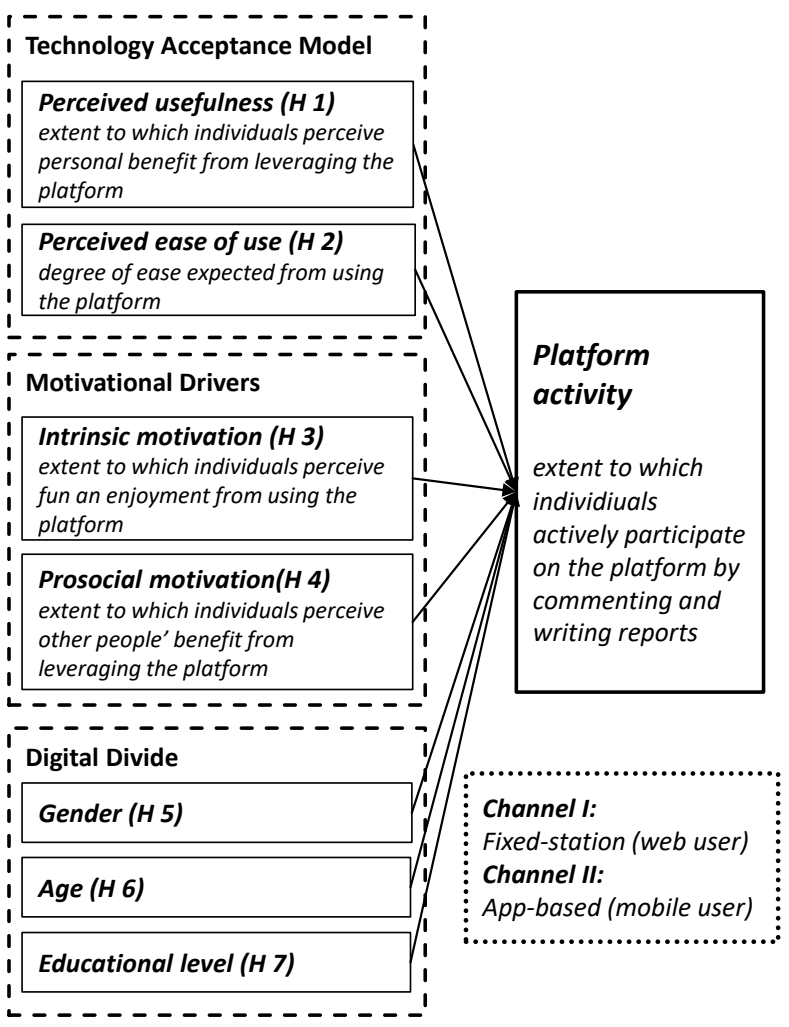

Figure 2. Research model

Table 5. Sample descriptives, web and mobile user

\begin{tabular}{|c|c|c|c|c|c|c|}
\hline \multirow[b]{2}{*}{ Variable } & \multicolumn{2}{|c|}{ Web \& app user } & \multicolumn{2}{|c|}{ Web user } & \multicolumn{2}{|c|}{ App user } \\
\hline & $N$ & $\begin{array}{l}\text { Mean } \\
\text { (S.D.) }\end{array}$ & $N$ & $\begin{array}{l}\text { Mean } \\
\text { (S.D.) }\end{array}$ & $N$ & $\begin{array}{l}\text { Mean } \\
\text { (S.D.) }\end{array}$ \\
\hline \multicolumn{7}{|c|}{ Socio-demographic criteria } \\
\hline Gender & 725 & $\begin{array}{l}.69 \\
(.46)\end{array}$ & 436 & $\begin{array}{l}.67 \\
(.47)\end{array}$ & 414 & $\begin{array}{l}.74 \\
(.44)\end{array}$ \\
\hline Age & 737 & & 444 & & 422 & \\
\hline young & 142 & $\begin{array}{l}.19 \\
(.39)\end{array}$ & 53 & $\begin{array}{l}.12 \\
(.32)\end{array}$ & 116 & $\begin{array}{l}.27 \\
(.45)\end{array}$ \\
\hline middle & 320 & $\begin{array}{l}.43 \\
(.5)\end{array}$ & 184 & $\begin{array}{l}.41 \\
(.49)\end{array}$ & 200 & $\begin{array}{l}.47 \\
(.5)\end{array}$ \\
\hline old & 275 & $\begin{array}{l}.37 \\
(.48)\end{array}$ & 207 & $\begin{array}{l}.47 \\
(.5)\end{array}$ & 106 & $\begin{array}{l}.25 \\
(.43)\end{array}$ \\
\hline Education & 733 & & 440 & & 422 & \\
\hline low & 189 & $\begin{array}{l}.26 \\
(.44)\end{array}$ & 105 & $\begin{array}{l}.24 \\
(.43)\end{array}$ & 110 & $\begin{array}{l}.26 \\
(.44)\end{array}$ \\
\hline middle & 303 & $\begin{array}{l}.41 \\
(.49)\end{array}$ & 181 & $\begin{array}{l}.41 \\
(.49)\end{array}$ & 169 & $\begin{array}{l}.4 \\
(.49)\end{array}$ \\
\hline high & 241 & $\begin{array}{l}.33 \\
(.47)\end{array}$ & 154 & $\begin{array}{l}.35 \\
(.48)\end{array}$ & 143 & $\begin{array}{l}.34 \\
(.47)\end{array}$ \\
\hline
\end{tabular}




\begin{tabular}{|c|c|c|c|c|c|c|}
\hline \multicolumn{7}{|c|}{ Platform behavior } \\
\hline $\begin{array}{l}\text { Frequency of } \\
\text { reading }\end{array}$ & 762 & $\begin{array}{l}3.63 \\
(1.19)\end{array}$ & 431 & $\begin{array}{l}3.61 \\
(1.18)\end{array}$ & 418 & $\begin{array}{l}3.75 \\
(1.15)\end{array}$ \\
\hline $\begin{array}{l}\text { Frequency of } \\
\text { commenting }\end{array}$ & 720 & $\begin{array}{l}1.78 \\
(.84)\end{array}$ & 401 & $\begin{array}{l}1.78 \\
(.85)\end{array}$ & 407 & $\begin{array}{l}1.85 \\
(.82)\end{array}$ \\
\hline $\begin{array}{l}\text { Frequency of } \\
\text { reporting }\end{array}$ & 746 & $\begin{array}{l}2.56 \\
(.92)\end{array}$ & 425 & $\begin{array}{l}2.56 \\
(.87)\end{array}$ & 411 & $\begin{array}{l}2.63 \\
(.94)\end{array}$ \\
\hline $\begin{array}{l}\text { Platform } \\
\text { activity }\end{array}$ & 715 & $\begin{array}{l}14.83 \\
(3.99)\end{array}$ & 398 & $\begin{array}{l}14.8 \\
(3.95)\end{array}$ & 404 & $\begin{array}{l}15.33 \\
(3.85)\end{array}$ \\
\hline
\end{tabular}

In addition to the correlation analysis (all correlation coefficients below .5), multicollinearity is checked by the tolerance value and the variance inflation factor. Furthermore, autocorrelation is checked by the Durbin-Watson-coefficient.

\subsection{Multivariate results}

The results of the multivariate analyses are presented in Table 6 (web users) and Table 7 (mobile users). Whereas perceived ease of use is not significantly associated with platform activity, linear regression analysis shows that perceived usefulness is positively related to platform activity, but only among web users. To the contrary, variables on motivation significantly influence platform activity of both types of users. Intrinsic motivation and prosocial motivation have a positive association with platform activity among web and mobile users. As far as socio-demographic characteristics are concerned, male web users show higher platform activity than women. To the contrary, gender has no effect on the intensity of use of mobile phone users. In both usage groups, results show that older users are less active on the platform than users below age 30. Education has hardly any effect on participation intensity. Whereas education is not significantly influencing platform behavior of web users, high-educated mobile users use the platform less actively than low educated ones.

\section{Discussion}

\subsection{Contributions and implications}

In this paper, we address the factors determining platform behavior of both web and app users to shed light on the innovative and technology-driven patterns of citizen-state interactions. Based on the technology acceptance model, motivation theory, and digital divide, we develop a research model and applied multivariate data analysis to test our hypotheses. We test the model among two groups of platform users: First, we identified the factors influencing platform activity among people using the platform via web browser. Second, we took a closer look at mobile phone users and those you have installed the application that enables them to communicate with local government. Descriptive results show that both users groups use the platform intensively. They read reports and comments, make own platform posts, and comment them.

Table 6. Regression results, web user

\begin{tabular}{|c|c|c|}
\hline \multirow[t]{2}{*}{ Web user } & \multicolumn{2}{|c|}{ Platform activity } \\
\hline & $\mathrm{b}$ & SE \\
\hline \multicolumn{3}{|l|}{ Technology } \\
\hline Perceived usefulness & $.116^{+}$ & .068 \\
\hline Perceived ease of use & .084 & .110 \\
\hline \multicolumn{3}{|l|}{ Motivation } \\
\hline Intrinsic motivation & $.237 * * *$ & .061 \\
\hline Prosocial motivation & $.473^{* *}$ & .162 \\
\hline \multicolumn{3}{|l|}{ Socio-demographic criteria } \\
\hline Gender (ref. female) & $.909 *$ & .430 \\
\hline \multicolumn{3}{|l|}{ Age (ref. young) } \\
\hline middle & -.235 & .601 \\
\hline old & $-1.64 * *$ & .63 \\
\hline \multicolumn{3}{|l|}{ Education (ref. low) } \\
\hline middle & -.265 & .536 \\
\hline high & -.619 & .54 \\
\hline Absolute term & $4.62 *$ & 2.12 \\
\hline \multicolumn{3}{|l|}{ Model fit } \\
\hline $\mathrm{R}^{2}$ & \multicolumn{2}{|c|}{.157} \\
\hline Adjusted $\mathrm{R}^{2}$ & \multicolumn{2}{|c|}{.134} \\
\hline F (Model. global) & \multicolumn{2}{|c|}{$6.63^{* * *}$} \\
\hline Number of observations & \multicolumn{2}{|c|}{329} \\
\hline${ }^{+} \mathrm{p}<0.10 ;^{*} \mathrm{p}<0.05 ;{ }^{* *}$ & $<0.001$ & \\
\hline
\end{tabular}

Table 7. Regression results, app user

\begin{tabular}{|c|c|c|}
\hline \multirow[t]{2}{*}{ App user } & \multicolumn{2}{|c|}{ Platform activity } \\
\hline & $\mathrm{b}$ & SE \\
\hline \multicolumn{3}{|l|}{ Technology } \\
\hline Perceived usefulness & .078 & .073 \\
\hline Perceived ease of use & .087 & .102 \\
\hline \multicolumn{3}{|l|}{ Motivation } \\
\hline Intrinsic motivation & $.167^{* *}$ & .056 \\
\hline Prosocial motivation & $.471^{* *}$ & .15 \\
\hline \multicolumn{3}{|l|}{ Socio-demographic criteria } \\
\hline Gender (ref. female) & -.275 & .437 \\
\hline \multicolumn{3}{|l|}{ Age (ref. young) } \\
\hline middle & -.485 & .449 \\
\hline old & $-1.69^{* *}$ & .548 \\
\hline \multicolumn{3}{|l|}{ Education (ref. low) } \\
\hline middle & -.454 & .495 \\
\hline high & $-1.01^{+}$ & .517 \\
\hline Absolute term & $7.53^{* * *}$ & 1.75 \\
\hline \multicolumn{3}{|l|}{ Model fit } \\
\hline$R^{2}$ & & 47 \\
\hline Adjusted $R^{2}$ & & 25 \\
\hline F (Model. global) & & $7 * * *$ \\
\hline Number of observations & & 58 \\
\hline
\end{tabular}


Empirical evidence on the antecedents of platform activity partly provides support for the technology acceptance model in the context of an open and digital government. Specifically, we show that users' perceived usefulness of communicating with local government by web platform increases their platform activity. This effect is not significant among respondents using the application for interaction. The influence of perceived ease of use on platform activity is insignificant for both sample respondents. These insignificant results are consistent with various prior studies on TAM $[10,57]$ and can be reasoned by the high level of technology experience of users.

In addition to TAM, this study investigates motivation theory to explain platform behavior. Regression analyses show that both intrinsic and prosocial motivation drive individuals to participate on the platform actively. According to these results, active users have an inherent interest in improving public services. They go online to inform local government about defects of public infrastructure and give suggestions on how to improve public service delivery. Additionally, they feel enjoyment when using the platform, discussing with other users, and share their opinions on public services.

Lastly, in investigating the use and non-use of open government, Wijnhoven et al. (2015) show that socio-demographic factors do not influence participation in government project. This current study partly confirms these results in terms of participation intensity. However, it points to differences with regard to the channel individuals utilize to participate. Our results show that, among web users, men more actively communicate on the platform than women. However, gender does not influence individuals' intensity of app use. It seems that the gender divide is disappearing with the spread of mobile technology and the possibility of relational use. Hampton et al. [17], for example, show that women use social media more frequently in the United States than men. In a similar vein, the educational level is influencing platform activity only among mobile users in a way that high-educated users use the platform less actively via app than loweducated ones. Nevertheless, regarding the sociodemographic factor age, in both user groups, younger users $(<30)$ are shown to be more active than older ones $(60+)$.

\subsection{Limitations and directions for future research}

In this analysis, we address the varying levels of platform activity of both web and app users. Thereby, we focus on factors influencing platform behavior and point to differences of the two samples analyzed. Whereas we are able to make statements on the drivers of platform activity (versus passive platform behavior) from both web and app users, first, this study does not distinguish between users and nonusers. Due to the increasing significance of digital government and citizen-state interactions by leveraging digital technology, future research on the individuals' motivation or barriers to communicate with government via platforms and applications would be valuable. In terms of non-use, it should also be examined, if people are not able or not willing to use technology for citizen-government communication. Second, this paper analyzes the antecedents of platform activity and consequently is not able to evaluate the effect of users' platform participation on public service improvement. Further researchers are well advised to address the benefits and costs of citizen participation in various contexts. It is interesting to assess the effect of citizens' input on quality of public services, citizen satisfaction with government, and efficiency of service delivery [6].

\section{References}

[1]Batson, C. D. (1998). Altruism and prosocial behavior. In D.T. Gilbert, S.T. Fiske, \& G. Lindzey (Eds.). The handbook of social psychology (4th ed., Vol. 2, pp. 282316). New York: McGraw-Hill.

[2]Bélanger, F., \& L. Carter. (2009). The impact of the digital divide on e-government use. Communications of the ACM, 52(4), 132-135.

[3]Best, S.J., \& Krueger, B. S. (2005). Analyzing the representativeness of Internet political participation. Political Behavior, 27(2), 183-216.

[4]Brabham, D.C. (2010). Moving the crowd at threadless: Motivations for participation in a crowdsourcing application. Information, Communication \& Society, 13 (8), 1122-1145.

[5]Bryant, S.L., Forte, A., \& A. Bruckman. (2005). Becoming wikipedian: Transformation of participation in a collaborative online encyclopedia. Paper presented at the Conference on Supporting group work (SIGGROUP 2005), Sanibel Island, FL, November 6-9.

[6]Buell, R.W., \& M.I. Norton. (2013). Surfacing the Submerged State with Operational Transparency in Government Services. Harvard Business School Marketing Unit Working Paper, 14-034, 1-23.

[7]Carter, L., \& F. Bélanger. (2005). The utilization of egovernment services: citizen trust, innovation and acceptance factors. Information Systems J, 15(1), 5-25. 
[8]Collier, B., \& J. Bear. (2012). Conflict, criticism, or confidence: an empirical examination of the gender gap in wikipedia contributions. In Proceedings of the ACM 2012 conference on computer supported cooperative work (pp. 383-392). ACM.

[9]Czaja, S.J., \& C.C. Lee. (2009). Information technology and older adults. In: A. Sears, \& J. A. Jacko (Eds). HumanComputer Interaction. Designing for Diverse Users and Domains. (pp. 17-32). CRC Press.

[10] Davis, F.D. (1989). Perceived usefulness, perceived ease of use, and user acceptance of information technology. MIS Quarterly, 13(3), 319-340.

[11] Davis, F.D., Bagozzi, R.P., \& P.R. Warshaw. (1989). User acceptance of computer technology: A comparison of two theoretical models. Management Science, 35(8), 982 1003 .

[12] Deci, E.L., \& R.M. Ryan. (2000). The "what" and "why" of goal pursuits: Human needs and the selfdetermination of behavior. Psychological Inquiry, 11(4), 227-268.

[13] Dimitrova, D.V., \& Y.C. Chen. (2006). Profiling the adopters of e-government information and services: The influence of psychological characteristics, civic mindedness, and information channels. Social Science Computer Review, 24(2), 172-188.

[14] Field, A. (2013). Discovering statistics using IBM SPSS statistics. Los Angeles: Sage.

[15] Glott, R., Schmidt, P., \& R. Ghosh. (2010). Wikipedia survey - Overview of results. United Nations University. UNU-MERIT.

[16] Hair, J.F., Black, W.C., Babin, B.J., Anderson, R.E., \& R. L. Tatham. (2006). Multivariate data analysis. 6th ed. Upper Saddle River, NJ: Pearson Prentice Hall.

[17] Hampton, K. N., Goulet, S. L., Rainie, L., \& K. Purcell. (2011). Social Networking Sites and Our Lives. Washington, DC: Pew Research Center's Internet and American Life Project.

[18] Hars, A., \& S. Ou. (2001). Working for free? Motivations of participating in open source projects. Proceedings of the 34th Annual Hawaii International Conference on System Sciences (HICSS), Hawaii, Jan 6.

[19] Heipke, C. (2010). Crowdsourcing geospatial data. ISPRS J of Photogrammetry and Remote Sensing, 65(6), 550-557.

[20] Hilgers, D. (2012). Open Government: Theoretische Bezüge und konzeptionelle Grundlagen einer neuen Entwicklung in Staat und öffentlichen Verwaltungen. Zeitschrift für Betriebswirtschaft, 82(6), 631-60.
[21] Hilgers, D., \& C. Ihl. (2010). Citizensourcing: Applying the concept of open innovation to the public sector. The Int Journal of Public Participation, 4(1), 67-88.

[22] Hutter, K., Füller, J. \& G. Koch. (2011). Why citizens engage in open government platforms? Paper presented at the 41. Jahrestagung der Gesellschaft für Informatik, Berlin, Oct 4-7.

[23] Jeppesen, L. B., \& K. R. Lakhani. (2010). Marginality and problem-solving effectiveness in broadcast search. Organization Science, 21(5), 1016-33.

[24] Jurisch, M. C., Kautz, M., Wolf, P., \& H. Krcmar. (2015). An international survey of the factors influencing the intention to use open government. Proceedings of the 48th Hawaii International Conference on System Sciences.

[25] Kersting, N. (2016). Politische Online-Beteiligung im internationalen Vergleich. Eine Revitalisierung politischer Beteiligung?. Z für Vergl Politikwissenschaft, 1-23.

[26] Kube, M., Hilgers, D., Koch, G., \& J. Füller. (2015). Explaining voluntary citizen online participation using the concept of citizenship: An explanatory study on an open government platform. Journal of Business Economics, 85(8), 873-895.

[27] Kurniawan, S. (2008). Older people and mobile phones: A multi-method investigation. International Journal of Human-Computer Studies, 66(12), 889-901.

[28] Lakhani, K. R., \& E. Von Hippel. (2003). How open source software works: "free" user-to-user assistance. Research policy, 32(6), 923-943.

[29] Lakhani, K. R., \& R. G. Wolf. (2005). Why hackers do what they do: Understanding motivation and effort in free/open source software projects. In J. Feller, B. Fitzgerald, S. Hissam, \& K. R. Lakhani (Eds). Perspectives on free and open source software (pp. 3-22). Cambridge MA, London: MIT Press.

[30] Lee, H., Irani, Z., Osman, I. H., Balci, A., Ozkan, S., \& T. D. Medeni. (2008). Research note: Toward a reference process model for citizen-oriented evaluation of e-government services. Transforming Government: People, Process and Policy, 2(4), 297-310.

[31] Lee, Y., Kozar, K. A., \& K. R. Larsen. (2003). The technology acceptance model: Past, present, and future. Communications of the Association for information system, 12(1), 752-780.

[32] Leech, N. L., Barrett, K. C., \& G. A. Morgan. (2005). SPSS for Intermediate Statistics: Use and Interpretation. 2nd ed. Mawah, NJ, London: Lawrence Erlbaum.

[33] Leimeister, J. M., Huber, M., Bretschneider, U., \& H. Krcmar. (2009). Leveraging crowdsourcing: Activationsupporting components for IT-based ideas competition. J of Management Information Systems, 26(1), 197-224. 
[34] Linders, D. (2012). From e-government to wegovernment: Defining a typology for citizen coproduction in the age of social media. Government Information Quarterly, 29(4), 446-454.

[35] Lukensmeyer, C., \& L. H. Torres. (2008). Citizensourcing: Citizen participation in a networked nation. In K. Yang \& E. Bergrud (Eds.), Civic engagement in a network society (pp. 207-233). Charlotte: Information Age Publishing.

[36] Luthiger, B., \& C. Jungwirth. (2007). Pervasive fun. First Monday 12 (1). doi:10.5210/fm.v12i1.1422

[37] Mergel, I. (2015). Opening government: Designing open innovation processes to collaborate with exter-nal problem solvers. Social Science Computer Review, 33(5), 599-612.

[38] Mergel, I., \& K. C. Desouza. (2013). Implementing open innovation in the public sector: The case of Challenge.gov. Public Administration Rev, 73(6), 882-890.

[39] Moon, M. J. (2002). The evolution of e-government among municipalities: rhetoric or reality?. Public Administration Review, 62(4), 424-433.

[40] Moon, M. J., Lee, J., \& C. Y. Roh. (2014). The Evolution of Internal IT Applications and e-Government Studies in Public Administration Research Themes and Methods. Administration \& Society, 46(1), 3-36.

[41] Mossberger, K., Tolbert, C. J., \& R. S. McNeal. (2007). Digital citizenship: The Internet, society, and participation. MIT Press.

[42] Nam, T. (2012). Suggesting frameworks of citizensourcing via Government 2.0. Government Information Quarterly, 29(1), 12-20.

[43] Norris, D. F., Fletcher, P. D., \& S. H. Holden. (2001). Is your local government plugged in? Highlights of the 2000 electronic government survey. Washington, DC: International City/County Management Association.

[44] Norris, P. (2001). Digital Divide: Civic Engagement, Information Poverty, and the Internet Worldwide. Cambridge: Cambridge University Press.

[45] Nunnally, J. C. (1978). Psychometric theory. 2nd ed. New York: McGraw-Hill.

[46] Oreg, S., \& O. Nov. (2008). Exploring motivations for contributing to open source initiatives: The roles of contribution context and personal values. Computers in Human Behavior, 24(5), 2055-2073.

[47] Oser, J., Hooghe, M., \& S. Marien. (2013). Is online participation distinct from offline participation? A latent class analysis of participation types and their stratification. Political Research Quarterly, 66(1), 91-101.
[48] Osterloh, M., \& S. Rota. (2007). Open source software development-Just another case of collective invention? Research Policy, 36(2), 157-171.

[49] Royo, S., \& A. Yetano. (2015). "Crowdsourcing" as a tool for e-participation: Two experiences regarding $\mathrm{CO} 2$ emissions at municipal level. Electronic Commerce Research, 15(3), 232-348.

[50] Send, H., Friesike, S., Ebert, J., Gollatz, K. \& T. Schildhauer. (2014). Online participation and decisionmaking. HIIG Discussion Paper Series. Discussion Paper 2014-07. Institut für Internet und Gesellschaft.

[51] Serdult, U., Germann, M., Mendez, F., Portenier, A., \& C. Wellig. (2015). Fifteen years of internet voting in Switzerland [History, Governance and Use]. In 2015 Second International Conference on eDemocracy \& eGovernment (ICEDEG) (pp. 126-132). IEEE.

[52] Thapa, B. E., Niehaves, B., Seidel, C. E., \& R. Plattfaut. (2015). Citizen involvement in public sector innovation: Government and citizen perspectives. Information Polity, 20(1), 3-17.

[53] Thomas, J. C. \& G. Steib. (2003). The new face of government: citizen-initiated contacts in the era of egovernment. Journal of Public Administration Research and Theory, 13(1), 83-102.

[54] Underhill, C. \& C. Ladds. (2007). Connecting with Canadians: Assessing the Use of Government On-Line. Research Paper. Science, Innovation and Electronic Information Division. Statistics Canada.

[55] Venkatesh, V., \& H. Bala. (2008). Technology acceptance model 3 and a research agenda on interventions. Decision Sciences, 39(2), 273-315.

[56] Venkatesh, V., Morris, M. G., Davis, G. B., \& F. D. Davis. (2003). User acceptance of information technology: Toward a unified view. MIS Quarterly, 27(3), 425-478.

[57] Wang, H., Chung, J. E., Park, N., McLaughlin, M. L. \& J. Fulk. (2012). Understanding online community participation: A technology acceptance perspective. Communication Research, 39(6), 781-801.

[58] Wijnhoven, F. Ehrenhard, M., \& J. Kuhn. (2015). Open government objectives and participation motivations. Government Information Quarterly, 32(1), 30-42.

[59] Wirtz, B. W., \& O. T. Kurtz. (2016). Citizen Preferences toward e-Government City Portals-An empirical Analysis of Full Online, Mobile and Social Media Services. Int Public Management Rev, 17(1), 1-20.

[60] Zeitlyn, D. (2003). Gift economies in the development of open source software: anthropological reflections. Research Policy, 32(7), 1287-1291. 